\title{
Malignant Oncocyte
}

National Cancer Institute

\section{Source}

National Cancer Institute. Malignant Oncocyte. NCI Thesaurus. Code C36942.

A malignant epithelial cell with abundant eosinophilic or clear granular cytoplasm. 